\title{
THE IMPACT OF THE COVID-19 PANDEMIC ON SEXUALLY TRANSMITTED INFECTIONS SERVICES - EXPERIENCE FROM BIALYSTOK, POLAND
}

\author{
WPEYW PANDEMII COVID-19 NA SYTUACJĘ W ZAKRESIE ZAKAŻEŃ \\ PRZENOSZONYCH DROGĄ PŁCIOWĄ \\ - DOŚWIADCZENIA OŚRODKA BIAŁOSTOCKIEGO
}

\author{
Department of Dermatology and Venereology, Medical University of Bialystok, Poland \\ Klinika Dermatologii i Wenerologii, Uniwersytet Medyczny w Białymstoku
}

\begin{abstract}
INTRODUCTION. COVID-19 pandemic had a big impact on the health services organisation, including that of sexually transmitted infections (STIs).

AIM. To analyse and evaluate the influence of COVID-19 epidemic on the detection of STIs and healthcare services in a group of these patients on the base of the experience of the Department of Dermatology and Venereology and University Outpatient Clinic in Bialystok, Poland.

MATERIAL AND METHODS. Analysis of the number of consultations for suspicion of STIs, number of newly diagnosed cases of syphilis, gonorrhoea, Chlamydia trachomatis infections and genital herpes in two periods: January 2019 - February 2020 (before the epidemic state was introduced) and March 2020 - April 2021 (during pandemic). STIs cases hospitalised in the same periods were also analysed.

RESULTS. The number of hospitalisations and outpatient consultations decreased during pandemic as compared to the period before it (by $83.3 \%$ and $41.9 \%$, respectively). Patients with syphilis constituted the majority in both periods, remaining STIs were few. During pandemic, the proportion of detected cases of syphilis was higher as compared to the time before it, despite the diminished number of consultations ( $39.4 \%$ and $28 \%$, respectively). Majority of patients with syphilis were men (92.3\% and 93.3\%), among them men-who-have-sex-with-men constituted at least $50 \%$. Early syphilis was diagnosed more frequently during pandemic than before it $(92.3 \%$ and $78.6 \%$, respectively), early symptomatic syphilis in particular $(46.2 \%$ and $35.7 \%$, respectively). HIV coinfection in syphilis patients was more frequent during pandemic ( $15.8 \%$ and $7.1 \%$, respectively). More than half of these patients (53.8\%) did not come for follow-up visits after treatment during pandemic.

CONCLUSIONS. The pandemic caused the decrease in number of outpatient STIs consultations and hospitalisations. The proportion of newly diagnosed cases of syphilis per number of consultations increased. The percentage of early syphilis cases, especially early symptomatic syphilis increased. Adherence to after treatment follow up was suboptimal.
\end{abstract}

Key words: COVID-19 pandemic, sexually transmitted infections, syphilis

\section{STRESZCZENIE}

WSTĘP. Pandemia COVID-19 znacząco wpłynęła na organizację usług medycznych, również w zakresie porad dermatologiczno-wenerologicznych.

CEL. Analiza i ocena wpływu stanu epidemii COVID-19 na wykrywalność zakażeń przenoszonych drogą płciową (ZPDP) i opiekę nad tymi pacjentami na podstawie doświadczeń Kliniki Dermatologii i Wenerologii i Uniwersyteckiej Poradni Dermatologicznej w Białymstoku.

MATERIAL I METODY. Analiza liczby porad udzielanych w Poradni pacjentom z podejrzeniem ZPDP, liczby nowo wykrytych przypadków kiły, rzeżączki, zakażeń Chlamydia trachomatis i opryszczki narządów

(C) National Institute of Public Health NIH - National Research Institute / Narodowy Instytut Zdrowia Publicznego PZH - Państwowy Instytut Badawczy 
płciowych w dwóch okresach: od stycznia 2019 r. do lutego 2020 r. (przed ogłoszeniem stanu epidemii) i od marca 2020 r. do kwietnia 2021 r. (w czasie pandemii). Analiza przypadków chorych z ZPDP hospitalizowanych w tym samym czasie w Klinice.

WYNIKI. Obserwowano spadek liczby hospitalizacji oraz porad ambulatoryjnych w okresie pandemii w stosunku do czasu przed nią (odpowiednio o 83,3\% i 41,9\%). Większość pacjentów w obu okresach chorowało na kiłę, pozostałe ZPDP były nieliczne. W czasie pandemii, pomimo mniejszej liczby porad, wykryto proporcjonalnie więcej przypadków kiły niż przed nią (odpowiednio: 39,4\% i 28\%). Większość pacjentów z kiłą stanowili mężczyźni (92,3\% i 93,3\%), wśród nich co najmniej połowę mężczyźni homoseksualni. W okresie pandemii częściej rozpoznawano kiłę wczesną ( $92,3 \%$ i 78,6\% przypadków), szczególnie objawową (46,2\% i 35,7\%). Współistnienie zakażenia HIV u chorych na kiłę stwierdzono częściej w okresie pandemii (15,8\% i 7,1\%). Ponad połowa chorych $(53,8 \%)$ nie zgłosiła się w tym czasie do wyznaczonych kontroli.

WNIOSKI. Pandemia wpłynęła na zmniejszenie liczby udzielanych porad w zakresie ZPDP oraz hospitalizacji. Zwiększyła się proporcjonalnie wykrywalność kiły w stosunku do liczby porad. Zwiększył się odsetek przypadków kiły wczesnej, a zwłaszcza objawowej. Kontrola po leczeniu kiły była niedostateczna.

Slowa kluczowe: pandemia COVID-19, zakażenia przenoszone droga płciowa, kita

\section{INTRODUCTION}

According to the most recent published World Health Organization (WHO) estimates there are 376.4 million new cases of four curable sexually transmitted infections (STIs), namely that of syphilis, gonorrhoea, trichomoniasis and Chlamydia (C.) trachomatis infections every year globally in the age group 15-49 years (1). In addition to direct symptoms of infections, STIs may lead to complications, sometimes irreversible ones, such as infertility, an adverse outcome of pregnancy and labour (miscarriage, preterm ending of pregnancy) or neonatal morbidity. STIs increase the risk of acquired a HIV infection.

The COVID-19 pandemic affected all aspects of life globally, such as health, social relationships or economics (2). It also forced the change of the existing health care services organisation, that in the field of dermatology and venereology, included (3).

\section{OBJECTIVE}

The aim of the study was to analyse and assess the impact of the pandemic on diagnosis and health care on patients with STIs based on the experience of Department of Dermatology and Venereology Medical University of Bialystok, Poland and the Outpatient Clinic of University Hospital in Bialystok.

\section{MATERIAL AND METHODS}

The retrospective analysis of medical records of patients with STIs hospitalized at the Department in two periods of time: before the implementation of epidemic state (January 2019 - February 2020, 14 months) and during epidemic state (March 2020 April 2021, 14 months) was conducted. Number of STIs outpatient consultations, that of newly diagnosed

\section{WSTĘP}

Według ostatnich danych publikowanych przez ekspertów Światowej Organizacji Zdrowia (World Health Organization - WHO) szacuje się, że w grupie osób w wieku 15-49 lat na świecie co roku u 376,4 milionów ludzi wykrywane są cztery, uznane za wyleczalne, zakażenia przenoszone drogą płciową (ZPDP) - kiła, rzeżączka, rzęsistkowica i chlamydioza (zakażenie Chlamydia - C. trachomatis) (1). Poza bezpośrednimi objawami ZPDP mogą prowadzić do powikłań, często nieodwracalnych, takich jak: niepłodność, niekorzystny przebieg ciąży i porodu (w tym poronienie, przedwczesne zakończenie ciąży), chorobowość noworodków. Zwiększają również ryzyko zakażenia HIV.

Pandemia COVID-19 na całym świecie wpłynęła na niemal wszystkie aspekty życia, w tym zdrowie, relacje społeczne, gospodarkę (2). Wymusiła także zmianę dotychczasowej organizacji udzielania świadczeń medycznych, także w zakresie dermatologii i wenerologii (3).

\section{CEL}

Celem pracy była analiza i ocena wpływu pandemii na wykrywalność ZPDP i opiekę nad tymi pacjentami na postawie doświadczeń Kliniki Dermatologii i Wenerologii Uniwersytetu Medycznego w Białymstoku oraz Poradni Dermatologicznej Uniwersyteckiego Szpitala Klinicznego (USK) w Białymstoku.

\section{MATERIAŁ I METODY}

Dokonano retrospektywnej analizy dokumentacji medycznej chorych z ZPDP hospitalizowanych w Klinice w dwóch okresach: przed ogłoszeniem stanu epidemii (od stycznia 2019 do lutego 2020 r. włącznie - 14 miesięcy) oraz po jego wprowadzeniu (od marca 2020 
cases of syphilis, gonorrhoea, C. trachomatis infection and genital herpes were retrospectively analysed in the same time spans. All patients had confirmed diagnosis, which is in line with European Union/ European Economic Area case definition (4). All syphilis cases were confirmed by positive serological tests results (both non-treponemal and treponemal), gonorrhoea cases - by positive gonococcal culture or polymerase chain reaction (PCR), C. trachomatis infection - with positive PCR; diagnosis of genital herpes was made on the ground of clinical picture. In cases of syphilis analysed characteristics included: age and sex of patients, the stage of diseases, co-existing STIs other than syphilis and adherence to follow-up visits during pandemic. For statistical analysis Student t-test, U Mann-Whitney test and a test of proportions were used (Statistica 13.3 TIBCO Software Inc. Palo Alto, CA USA) and the level of significance was set at $\alpha=0.05$.

\section{RESULTS}

Because of relocation of the important part of the medical staff to COVID-19 departments the Department of Dermatology and Venereology was closed since March 25th till May 31st 2020 and, subsequently, since October 22 2020 till August 2021; it is still closed on the day of the submission of the manuscript. The outpatient clinic was open continuously during pandemic but mainly on-phone consultations were provided between March and May 2020 . No case of STI has been diagnosed solely by onphone consultation.

The characteristics of 14 patients with syphilis in both periods analysed are presented in Table I. In the period before pandemic one male patient with disseminated gonococcal infection was also hospitalized. During pandemic two patients were hospitalized (decline by $83.3 \%$ ), both with secondary syphilis and co-infection with HIV; in one of them an ocular syphilis was also diagnosed. In none patient hepatotropic viral infection was diagnosed, but appropriate laboratory tests were not conducted in four patients. Tests for Mycoplasma genitalium nor these for Ureaplasma urealyticum were not performed.

Sixty-two and 36 consultations for STIs were conducted in the outpatient clinic in the period before pandemic and during it, respectively (decline by $41.9 \%$ ). Consultations for the suspicion of syphilis constituted the highest proportion (Table II).

The characteristics of patients with acquired syphilis diagnosed in the outpatient clinic are presented in Table II. Additionally, one case of congenital syphilis was diagnosed before epidemic. Gonococcal infection was diagnosed in three males (aged: 27, 32 and 33 r. do kwietnia 2021 r. - 14 miesięcy). Przeanalizowano retrospektywnie liczbę porad udzielanych w Poradni Dermatologicznej USK pacjentom z ZPDP, dokumentację medyczną nowo wykrytych przypadków kiły, rzeżączki, zakażeń $C$. trachomatis i opryszczki narządów płciowych $\mathrm{w}$ analogicznych okresach. U wszystkich chorych zakażenia rozpoznano zgodnie $z$ definicją przypadku na potrzeby nadzoru epidemiologicznego, który jest zgodny $\mathrm{z}$ definicją schorzenia w Unii Europejskiej (4). Wszystkie przypadki kiły były potwierdzone dodatnimi wynikami badań serologicznych (odczynami niekrętkowymi i krętkowymi), rzeżączki - dodatnim wynikiem hodowli lub badania molekularnego (ang. polymerase chain reaction - PCR), zakażenia C. trachomatis - dodatnim wynikiem badania PCR; rozpoznanie opryszczki narządów płciowych stawiano na podstawie obrazu klinicznego. W przypadkach kiły analizowano wiek i płeć pacjentów, okres choroby, zakażenia współistniejące oraz zgłaszalność pacjentów do kontroli w okresie pandemii. Analizę statystyczną przeprowadzono przy pomocy testu t-Studenta, U Manna-Whitneya oraz testu dla dwóch wskaźników struktury (Statistica 13.3 TIBCO Software Inc. Palo Alto, CA, USA), przyjmując poziom istotności $\alpha=0,05$.

\section{WYNIKI}

Klinika Dermatologii i Wenerologii, ze względu na oddelegowanie znaczącej części personelu medycznego do oddziałów covidowych, nie przyjmowała pacjentów ze schorzeniami dermatologicznymi i przenoszonymi droga płciową od 25.03.2020 r. do 31.05 .2020 r. i od 22.10.2020 do sierpnia 2021 r., tj do dnia przyjęcia manuskryptu wciąż nie przyjmuje pacjentów. Poradnia działała nieprzerwanie w okresie pandemicznym, od marca do maja 2020 r. udzielano głównie teleporad. Żaden przypadek ZPDP nie był zdiagnozowany wyłącznie w drodze teleporady.

Charakterystykę czternastu pacjentów z kiłą hospitalizowanych w Klinice w obu analizowanych okresach przedstawiono w Tabeli I. W pierwszym okresie hospitalizowano także 42-letniego pacjenta $\mathrm{z}$ rozsianym zakażeniem rzeżączkowym. Pacjenci z innymi ZPDP nie byli hospitalizowani. W okresie pandemii z powodu kiły hospitalizowano dwóch pacjentów (spadek o 83,3\%) z kiłą drugiego okresu i współistniejącym zakażeniem HIV, $\mathrm{u}$ jednego $\mathrm{z}$ nich rozpoznano współistniejącą kiłę narządu wzroku. U żadnego pacjenta w obu analizowanych okresach nie stwierdzono zakażenia wirusami hepatotropowymi, ale u czterech pacjentów badań w tym kierunku nie wykonano. Badań w kierunku Mycoplasma genitalium ani Ureaplasma urealyticum nie przeprowadzano. 
years, two of them were men who have sex with men - MSM and one - heterosexual) and in one 29-yearold female, before and during epidemic, respectively. Genital herpes was diagnosed in four males in the first period analysed (aged: 42, 34, 30 and 29 years) and in one (35-year-old) - in the second one. All infections were caused by a single pathogen. No isolated case of C. trachomatis infection was detected. Infections coexisting with syphilis are presented in Table I and II.
W pierwszym analizowanym okresie udzielono ambulatoryjnie 62 konsultacji pacjentom $\mathrm{z}$ podejrzeniem ZPDP, a w drugim - 36 (spadek o 41,9\%). Największy odsetek porad w zakresie ZPDP stanowiły podejrzenia kiły (Tabela II).

Charakterystykę pacjentów z kiłą nabytą rozpoznaną w Poradni przedstawiono w Tabeli II. Rozpoznano ponadto przed epidemią jeden przypadek kiły wrodzonej. Rzeżączkę rozpoznano u trzech mężczyzn (w wieku 27, 32 i 33 lat, dwóch mężczyzn utrzymu-

Table I. Patients with syphilis hospitalized at the Department of Dermatology and Venereology

Tabela I. Pacjenci z kiłą hospitalizowani w Klinice Dermatologii i Wenerologii

\begin{tabular}{|c|c|c|c|c|}
\hline & & $\begin{array}{l}\text { January } 2019- \\
\text { February } 2020\end{array}$ & $\begin{array}{c}\text { March } 2020- \\
\text { April } 2021\end{array}$ & $P$ value \\
\hline \multicolumn{2}{|c|}{ Number of patients newly diagnosed with syphilis } & 12 & 2 & \\
\hline \multicolumn{2}{|c|}{ Age in years: mean value \pm standard deviation, range } & $\begin{array}{c}29.3 \pm 8.1 \\
17-36\end{array}$ & $33-51$ & NS \\
\hline \multicolumn{2}{|c|}{ Males $(\%)$} & $11(91.7)$ & $2(100)$ & NS \\
\hline \multicolumn{2}{|c|}{ MSM $(\%)$} & $6(54.5)$ & $1(50)$ & NS \\
\hline \multirow{4}{*}{ Stage of syphilis (\%) } & Early symptomatic & $9(75.0)$ & $2(100)$ & NS \\
\hline & Early latent & 0 & 0 & \\
\hline & Late latent & $1(8.3)$ & 0 & NS \\
\hline & Unknown duration & $2(16.7)$ & 0 & NS \\
\hline \multirow{4}{*}{ Concomitant STIs (\%) } & HIV & $1(8.3)$ & $2(100)$ & 0.04 \\
\hline & Gonorrhoea & $1(8.3)$ & 0 & NS \\
\hline & C. trachomatis & $2(16.7)$ & 0 & NS \\
\hline & HPV & $2(16.7)$ & 0 & NS \\
\hline
\end{tabular}

NS - not statistically significant, HIV - human immunodeficiency virus, HPV - human papilloma virus

Table II. Patients with acquired syphilis consulted in University Outpatients Clinic (one case of congenital syphilis was additionally diagnosed)

Tabela II. Pacjenci z kiłą nabytą konsultowani w Poradni Dermatologicznej USK (rozpoznano także jeden przypadek kiły wrodzonej)

\begin{tabular}{|c|c|c|c|c|}
\hline & & $\begin{array}{l}\text { January } 2019- \\
\text { February } 2020\end{array}$ & $\begin{array}{l}\text { March } 2020- \\
\quad \text { April } 2021\end{array}$ & $P$ value \\
\hline \multicolumn{2}{|c|}{$\begin{array}{l}\text { Number of new patients consulted for suspicion of } \\
\text { syphilis ( } \% \text { of all consultations for STIs) }\end{array}$} & $50(80.6)$ & $33(91.7)$ & \\
\hline \multicolumn{2}{|c|}{ Number $(\%)$ of patients newly diagnosed with syphilis } & $14(28)$ & $13(39.4)$ & NS \\
\hline \multicolumn{2}{|c|}{ Age in years: mean value \pm standard deviation, range } & $\begin{array}{c}30.4 \pm 10.2 \\
18-40\end{array}$ & $\begin{array}{c}34.6 \pm 9.9 \\
23-57\end{array}$ & NS \\
\hline \multicolumn{2}{|c|}{ Males $(\%)$} & $13(92.9)$ & $12(92.3)$ & NS \\
\hline \multicolumn{2}{|c|}{ MSM (\%) } & $7(53.9)$ & $6(50)$ & NS \\
\hline \multirow{4}{*}{ Stage of syphilis } & Early symptomatic & $5(35.7)$ & $6(46.2)$ & NS \\
\hline & Early latent & $6(42.9)$ & $6(46.2)$ & NS \\
\hline & Late latent & $1(7.1)$ & 0 & NS \\
\hline & Unknown duration & $2(14.3)$ & $1(7.7)$ & NS \\
\hline \multirow{3}{*}{ Concomitant STIs (\%) } & HIV & $1(7.1)$ & $2(15.8)$ & NS \\
\hline & C. trachomatis & $4(28.6)$ & $3(23.1)$ & NS \\
\hline & HPV & $3(21.4)$ & 0 & NS \\
\hline
\end{tabular}

NS - not statistically significant, HIV - human immunodeficiency virus, HPV - human papilloma virus 
Patients with syphilis (these hospitalized and outpatient together) constituted $76.5 \%$ and $88.2 \%$ of all STI patients in the period before pandemic and during it, respectively. Among 26 patients diagnosed with syphilis before epidemic (hospitalised and consulted in outpatient clinic together) - $12(46.2 \%)$ had at least one after treatment follow-up visit conducted during epidemic.

\section{DISCUSSION}

The state of epidemic threat was implemented by Polish government on March $12^{\text {th }}$ and the state of epidemic - on March $20^{\text {th }} 2020$ (5). In 2017 and 2018, 1593 and 1445 syphilis cases were reported respectively, 321 and 332 - gonorrhoea cases, 258 and 308 cases of $C$. trachomatis infections. Since the beginning of 2019 till the end of March 2020, 1915 cases of syphilis (832 cases of early syphilis included), 630 cases of gonorrhoea and 494 cases of $C$. trachomatis infections were reported in Poland (6). During pandemic (March 2020 - March 2021) the number of reported STIs cases diminished significantly: 633 cases of syphilis (312 cases of early syphilis included), 189 cases of gonorrhoea and 133 cases of C. trachomatis infection cases were reported - data on 2021 available only from biweekly reports $(6,7)$. The decline was the smallest for early syphilis cases (by 62.5\%), the highest one - for C. trachomatis infection cases, which are frequently, especially in women, asymptomatic or oligosymptomatic (by $73.1 \%$ ). Similar data, indicating the decline in reported cases of communicable disorders during lockdown, including STIs, were published from Switzerland: the decline was as high as by $84.8 \%$ for early syphilis comparing mean values for years 2016-2019 (8). In Podlaskie voivodeship (where Bialystok is the capital and the largest city) 23 cases of early syphilis, $18-$ of gonorrhoea and 23 - of chlamydial infections were reported in 2019. In 2020 and the first quarter $2021-$ the number of cases was: nine, seven and 14 for early syphilis, gonorrhoea and $C$. trachomatis infections, respectively (9). In contrast to entire country, the highest decline was notices for early syphilis (by $60.9 \%$ ), the lowest - for C. trachomatis infections (by $39.1 \%$ ). The discrepancies between the number of cases reported by Provincial Sanitary and Epidemiological Station and the number of cases diagnosed in the similar period at the Department and Outpatient clinic may result from incomplete reporting of STIs in our centre but also other dermatological-venereological settings in the Province.

To summarize results, we found that majority of STI patients were those with syphilis and other STIs were rare. Despite the decline in the number of jących kontakty z mężczyznami, ang. men who have sex with men - MSM, jednego o orientacji heteroseksualnej) w okresie przed epidemią i u 29-letniej kobiety w drugim okresie. Opryszczkę narządów płciowych rozpoznano u czterech mężczyzn w pierwszym z analizowanych okresów (w wieku 42, 34, 30 i 29 lat) i u jednego (35-letniego) w drugim. Były to zakażenia wyłącznie jednym $z$ powyższych patogenów. Nie stwierdzono izolowanych zakażeń $C$. trachomatis. Zakażenia współistniejące $\mathrm{z}$ kiłą przedstawiono w Tabelach I i II.

Pacjenci chorzy na kiłę ogółem hospitalizowani i leczeni ambulatoryjnie stanowili odpowiednio 76,5\% i $88,2 \%$ wszystkich chorych z ZPDP w okresie przed i w trakcie pandemii. Spośród 26 pacjentów z kiłą zdiagnozowaną łącznie w Klinice i Poradni w okresie przedepidemicznym $12(46,2 \%)$ zgłosiło się przynajmniej na jedną wizytę kontrolną po leczeniu w trakcie epidemii.

\section{DYSKUSJA}

Rząd polski ogłosił stan zagrożenia epidemicznego 12 marca, a stan epidemii w dniu 20 marca 2020 r. (5). W Polsce w latach 2017 i 2018 zgłoszono odpowiednio 1593 i 1445 przypadków kiły, 321 i 332 przypadki rzeżączki oraz 258 i 308 przypadków zakażeń $C$. trachomatis. Od początku 2019 roku i w pierwszym kwartale 2020 r. liczba zgłoszonych przypadków kiły wynosiła 1915 (w tym 832 - kiły wczesnej), rzeżączki - 630 a zakażeń C. trachomatis 494 (6). W okresie pandemii, od kwietnia 2020 r. do końca pierwszego kwartału 2021 r. liczba raportowanych ZPDP obniżyła się znacząco: zgłoszono 633 przypadki kiły (w tym 312 - kiły wczesnej), 189 przypadki rzeżączki i 133 przypadki zakażeń $C$. trachomatis - dane z $2021 \mathrm{r}$. dostępne tylko z meldunków dwutygodniowych $(6,7)$. W porównywanych okresach najmniejszy spadek zgłoszonych przypadków odnotowano dla kiły wczesnej (o 62,5\%), największy (o 73,1\%) - dla zakażeń chlamydialnych, które często przebiegają skąpo lub bezobjawowo, szczególnie u kobiet. Podobne dane dotyczące spadku zgłaszanych ZPDP w okresie „lockdownu" pochodzą ze Szwajcarii: aż o $84,8 \%$ w przypadku kiły wczesnej $\mathrm{w}$ stosunku do średniej $\mathrm{z}$ lat 2016-19 (8). W województwie podlaskim w 2019 r. odnotowano 23 przypadki kiły wczesnej, 18 - rzeżączki i 23 - zakażeń chlamydialnych, w 2020 r. i pierwszym kwartale 2021 r., odpowiednio: dziewięć, siedem i 14 (9). Inaczej niż w całym kraju najwyższy spadek raportowanych przypadków stwierdzono dla kiły wczesnej (o 60,9\%), najmniejszy (o 39,1\%) - dla zakażeń chlamydialnych. Rozbieżności w liczbie przypadków kiły wczesnej raportowanych dla celów epidemiologicznych przez Wojewódzką Stację Sanitarno-Epide- 
outpatient consultations by more than $40 \%$, the number of diagnosed cases of syphilis was similar and the proportion of detected cases in relation to the number of consultations - higher. Similarly to our previous observation vast majority of these patients were males, about half of them were MSM (10). The mean age of patients diagnosed during epidemic was higher. The proportion of patients with early symptomatic syphilis (primary and secondary) increased. More than half of patients did not attend any of scheduled follow-up visits after treatment during pandemic, which is in accordance with our previous study results (10).

The European studies on the impact of COVID-19 pandemic on STIs epidemiology are scarce so far, but gave similar results to our observations. Authors from Milan demonstrated that despite the decline of STIs diagnosed in March - May 2020, as compared to the corresponding period in 2019, the number of acute symptomatic bacterial infections (such as gonorrhoea or secondary syphilis) increased, especially among MSM (11). Authors concluded, that pandemic and related to it restriction in social activity, did not influenced risky sexual behaviour in this group of patients (11). Similarly, since the beginning of lockdown the decline in STIs diagnosed in an STI/ HIV clinic in Rome was noticed but the number of new syphilis cases in the first quarter of 2020 increased, as compared to the same period in 2019, four-times among MSM (12). Also, other authors observed that social contacts' limitations did not reduce risky sexual behaviours and the number of newly diagnosed STIs in March - May 2020 was similar as in March - May 2019 , and, as in our study, the majority of patients were symptomatic (13). The comprehensive study involving 34 European WHO region countries (98 centres) shown the decline in tests for HIV, HBV, HCV and syphilis performance in $95 \%$ of those settings in March - May 2020 as compared with pre-COVID-19 period. In $64 \%$ of centres the decrease was by more than $50 \%$. Reasons for the decrease included: testing site closure during lockdown, relocation of staff, reduction of faceto-face appointments and more frequent on-phone consultations (14).

Restrictions during COVID-19 pandemic (social distancing, self-isolation, closure of bars, restaurants, limited travels) diminished the possibility to find a new sexual partner and potentially could promote safer sexual activity (3). On the other hand, the difficulties in obtaining professional medical help and treatment during lockdown contributed to longer infectiousness time of already acquired STIs (3). Moreover, after the pandemic, especially in high-risk groups, sexual activity can be expected to increase. miologiczną a liczbą przypadków zdiagnozowanych w Klinice i Poradni w okresie epidemii mogą wynikać z niedostatecznej zgłaszalności z tutejszego ośrodka, a także innych ośrodków dermatologiczno-wenerologicznych w województwie.

Podsumowując wyniki, większość pacjentów w obu okresach stanowili chorzy na kiłę. Inne ZPDP były nieliczne. Pomimo, że liczba porad udzielanych ambulatoryjnie uległa w okresie epidemii zmniejszeniu o ponad $40 \%$, to liczba nowo wykrytych przypadków kiły była podobna, a proporcja wykrytych przypadków w stosunku do liczby porad - wyższa. Podobnie do wcześniejszych obserwacji zdecydowaną większość w obu okresach stanowili mężczyźni, a wśród nich około połowę - MSM (10). Średnia wieku pacjentów z okresu epidemii była wyższa. Wzrosła proporcja pacjentów z kiłą wczesną objawową (pierwszego i drugiego okresu). W okresie epidemii do żadnej z planowanych wizyt kontrolnych po leczeniu kiły nie zgłosiła się ponad połowa pacjentów zdiagnozowanych przed pandemią, co nie różni się od obserwacji z naszych wcześniejszych badań (10).

Wyniki niniejszego badania $\mathrm{w}$ dużej mierze są zgodne z danymi z nielicznych jeszcze prac oceniających wpływ pandemii COVID-19 na sytuację epidemiologiczną $\mathrm{w}$ zakresie ZPDP $\mathrm{z}$ innych europejskich ośrodków. Badacze z Mediolanu wykazali, że chociaż liczba wykrywanych ZPDP zmalała w okresie od marca do kwietnia $2020 \mathrm{r}$. w porównaniu $\mathrm{z}$ analogicznym okresem 2019 r., to w przypadku zakażeń bakteryjnych o ostrym, objawowym przebiegu (takich, jak rzeżączka, kiła drugiego okresu) odnotowano wzrost, szczególnie wśród MSM (11). Autorzy wnioskowali, że pandemia i związane z nią ograniczenie aktywności społecznej nie wpłynęły na ryzykowne zachowania seksualne w tej grupie pacjentów (11). Podobnie, od początku „lockdownu” zaobserwowano zdecydowane zmniejszenie ogólnej liczby zdiagnozowanych ZPDP w ośrodku w Rzymie, ale liczba nowych przypadków kiły w pierwszym kwartale 2020 r. wzrosła w stosunku do analogicznego okresu 2019 r., a wśród MSM aż czterokrotnie (12). Inni autorzy zwracają uwagę, że restrykcje dotyczące kontaktów społecznych nie wpłynęły znacząco na ryzykowne kontakty seksualne, a liczba nowo zdiagnozowanych ZPDP w okresie „lockdownu” (marzec - maj 2020 r.) była, podobnie jak $\mathrm{w}$ niniejszym badaniu, porównywalna $\mathrm{z}$ takim samym okresem 2019 r., a zdecydowana większość pacjentów miała objawy i dolegliwości (13). Szeroko zakrojone badanie obejmujące 34 kraje europejskiego regionu WHO (łącznie 98 ośrodków) wykazało, że w 95\% przypadków liczba wykonywanych badań laboratoryjnych w kierunku HIV, HBV, HCV oraz kiły, rzeżączki i zakażeń $C$. trachomatis uległa obniżeniu od marca do maja 2020 r. w porównaniu z takim sa- 


\section{CONCLUSIONS}

COVID-19 pandemic affected the STIs situation. Despite a reduction of STI outpatient consultations the number of newly diagnosed STIs, and especially syphilis cases, remained similar as compared with the pre-pandemic period, but it was proportionally higher considering the number of consultations. The percentage of early syphilis, especially early symptomatic syphilis, increased. The attendance to follow-up visits remained suboptimal. Results suggest clearly that venereological health care system (both possibility of hospitalisation and face-to-face outpatient consultations) should be fully restored.

\section{REFERENCES}

1. Rowley J, Vander Hoorn S, Korenromp E, et al. Chlamydia, gonorrhoea, trichomoniasis and syphilis: global prevalence and incidence estimates, 2016. Bull World Health Organ. 2019;97(8):548$562 \mathrm{P}$.

2. Dhama K, Sharun K, Tiwari R, et al. Coronavirus disease 2019-COVID-19. Clin Microbiol Rev 2020;33:e00028-20.

3. Ogunbodede OT, Zablotrska-Manos I, Lewis DA. Potential and demonstrated impacts of the COVID-19 pandemic on sexually transmissible infections. Curr Opin HIV AIDS 2021; 16(2):11520.

4. Narodowy Instytut Zdrowia Publicznego - PZH. Definicje przypadków chorób zakaźnych na potrzeby nadzoru epidemicznego Warszawa luty 2020. Available at: http://wwwold.pzh.gov.pl/ oldpage/epimeld/inne/Def PL2 6b.pdf

5. Rozporządzenie Ministra Zdrowia $\mathrm{z}$ dnia 20 marca 2020 r. w sprawie ogłoszenia na obszarze Rzeczypospolitej Polskiej stanu epidemii. Dz.U. 2020 poz.491. Available at: http://isap.sejm.gov.pl/ isap.nsf/DocDetails.xsp?id=WDU20200000491

6. Narodowy Instytut Zdrowia Publicznego PZH Państwowy Instytut Badawczy. Choroby zakaźne i zatrucia w Polsce w 2020 roku. Biuletyn roczny. Available at: http://wwwold.pzh.gov.pl/oldpage/ epimeld/2020/Ch 2020 Wstepne dane.pdf

7. Narodowy Instytut Zdrowia Publicznego PZH - Państwowy Instytut Badawczy. Meldunki ozachorowaniach na choroby zakaźne, zakażeniach i zatruciach w Polsce (dwutygodniowe). Available at: http://wwwold.pzh.gov.pl/oldpage/epimeld/ index_p.html

8. Steffen R, Lautenschlager S, Fehr J. Travel restrictions and lockdown during the COVID-19 pandemic-impact on notified mym okresem 2019 r. W 64\% ośrodków liczba badań zmniejszyła się o ponad 50\%. Wśród najczęściej wymienianych przyczyn tego zjawiska wskazywano na zamknięcie ośrodków, w których pobierany jest materiał do badań laboratoryjnych, przeniesienie personelu do ośrodków związanych bezpośrednio z walką z COVID-19, zmniejszenie liczby wizyt w poradniach, częstsze teleporady (14).

Obostrzenia w trakcie pandemii COVID-19 (dystans społeczny, samoizolacja, zamknięcie barów i dyskotek, ograniczenia w podróżowaniu) miały wpływ na zmniejszenie możliwości spotkania nowego partnera seksualnego i mogły skłaniać do bezpieczniejszych form aktywności seksualnej (3). Z drugiej strony, utrudniony dostęp do porad medycznych przyczyniał się do wydłużonego czasu zakaźności już nabytych ZPDP (3). Ponadto, można spodziewać się zwiększonej aktywności seksualnej, szczególnie w grupach o ryzykownych zachowaniach seksualnych, po wygaśnięciu pandemii.

\section{WNIOSKI}

Pandemia COVID-19 miała wpływ na sytuację epidemiologiczną w zakresie ZPDP. Pomimo znacznego zmniejszenia liczby porad w zakresie wenerologii w tym okresie, liczba wykrytych przypadków ZPDP, a zwłaszcza kiły, była podobna jak w okresie przed epidemią, natomiast była proporcjonalnie większa w stosunku do liczby udzielonych porad. Zwiększył się odsetek kiły wczesnej, a zwłaszcza objawowej. Zgłaszalność do kontroli po leczeniu pozostała, podobnie jak w ubiegłych latach, niedostateczna. Wyniki wyraźnie wskazują, że możliwość hospitalizacji oraz poradnictwo w zakresie wenerologii powinny być przywrócone w pełnym zakresie.

infectious diseases in Switzerland. J Travel Med. 2020;27(8):taaa180.

9. Ocena stanu sanitarnego województwa podlaskiego - Wojewódzka Stacja SanitarnoEpidemiologiczna w Białymstoku - Portal Gov. pl (www.gov.pl). Available at: https://www. gov.pl/attachment/6a9b3207-432a-4fab-a704ce741bac501c

10. Serwin AB, Grochowska A, Flisiak I. Men treated for syphilis in Białystok, Poland, 2014-2018. Przegl Epidemiol 2019;73(3):329-335.

11. Cusini M, Bernardon S, Vidoni L, et al: Trend of main STIs during COVID_19 pandemic in Milan, Italy. Sex Transm. Infect 2021;97(2):99.

12. Latini A, Magri F, Dona MG, et al. Is COVID-19 affecting the epidemiology of STIs. The 
experience of syphilis in Rome. Sex Transm Infect 2021;97(1):78.

13. Balestri R, Magnano M, Rizzoli L, et al. STIs and the COVID-19 pandemic: the lockdown does not stop sexual infections. J Eur Acad Dermatol Venereol. 2020;34(12):e766-e768.

14. Simoes D, Rinder Stengaard A, Combs L, et al. Impact of the COVID-10 pandemic on testing services for HIV, viral hepatitis and sexually transmitted infections in the WHO European Region, March to August 2020. Euro Surveill 2020;25(47):2001943.
Received: 09.07.2021

Accepted for publication: 17.08.2021

Otrzymano: 09.07.2021 r.

Zaakceptowano do publikacji: 17.08.2021 r.

Address for correspondence:

Adres do korespondencji:

Ass. Prof. Agnieszka B. Serwin

Department of Dermatology and Venereology,

Medical University of Bialystok

14, Żurawia St., 15-540 Bialystok, Poland

Phone: (+48) 857409559, fax: (+48) 857409406

e-mail: agabser@umb.edu.pl 